\title{
Pemberdayaan Usaha Ekonomi Produktif Melalui Pendekatan Sistem Pelatihan dan Pendampingan Petani Lebah Madu
}

\author{
Idris Yanto Niode', Rustam Tohopi ${ }^{2}$, Endi Rahman ${ }^{3}$ \\ 1,3 Jurusan Manajemen, Fakultas Ekonomi, Universitas Negeri Gorontalo, J1. Jend. \\ Sudirman No. 6 Kota Gorontalo, Gorontalo 96128, Indonesia \\ 2 Jurusan Administrasi Publik, Fakultas Ilmu Sosial, Universitas Negeri Gorontalo, J1. Jend. \\ Sudirman No. 6 Kota Gorontalo, Gorontalo 96128, Indonesia \\ E-mail: idris_niode@ung.ac.id ${ }^{1}$, $\underline{\text { rustamtohopi@ung.ac.id }}^{2}, \underline{\text { endhy_80@ung.ac.id }}^{3}$
}

Article History:

Received: 19-11-2021

Revised: 26-11-2021

Accepted: 28-11-2021

Keywords: Usaha Lebah

Madu, Peningkatan

Perekonomian

\begin{abstract}
:
Tujuan dari program kegiatan ini adalah memberikan dorongan/ spirit kepada kelompok tani/ usaha lebah madu untuk meningkatkan produktifitasnya dalam rangka peningkatan ekonomi tani lebah madu dan masyarakat desa Maleo pada umumnya melalui budidaya/ ternak lebah madu. Hal ini bisa dicapai bila para petani lebah memiliki pengetahuan dan keterampilan bagaimana menghasilkan produk yang teruji kualitasnya tidak hanya hasil produksi utama yakni madu akan tetapi juga meliputi Lilin, Propolis, Royal Jelly, dan Tepung Sari/ Pollen yang juga dihasilkan dari lebah madu. Kelompok masyarakat sasaran adalah masyarakat petani yang telah memiliki usaha ternak lebah madu tetapi membutuhkan pendampingan untuk melakukan kegiatan peningkatan produksi dan pemasaran hasil produksinya. Keberadaan program ini diharapkan akan membantu kelompok tani lebah madu dengan memberikan metode pelatihan dan bimbingan teknis produksi dan pengemasan.
\end{abstract}

\section{Pendahuluan}

Lebah madu merupakan salah satu sumber daya hutan yang potensial untuk dikembangkan dalam pembudidayaannya, hal ini disebabkan karena sumber pakan lebah yang melimpah (hampir semua tumbuhan yang menghasilkan bunga dapat dijadikan sebagai sumber pakan) baik yang berasal dari tanaman hutan, tanaman pertanian maupun tanaman perkebunan. Produk yang dihasilkan oleh lebah madu dapat dimanfaatkan dan mempunyai nilai ekonomi yang cukup tinggi, seiring dengan meningkatnya jumlah penduduk dan berkembangnya teknologi maka tingkat pemanfaatan produk yang dihasilkan oleh lebah madu semakin meningkat baik untuk kepentingan konsumsi atau obat-obatan, dan permintaan pasar akan produk yang dihasilkan oleh lebah madu semakin tinggi.

Desa Maleo sendiri merupakan daerah yang memiliki luas perkebunan $266 \mathrm{ha} / \mathrm{m}^{2}$ serta dikelilingi hutan produksi $347 \mathrm{ha} / \mathrm{m}^{2}$ dan hutan rakyat $273 \mathrm{ha} / \mathrm{m}^{2}$ sehingga total luas hutan 620 $\mathrm{ha} / \mathrm{m}^{2}$. Selain itu desa Maleo sendiri didukung dengan kondisi topografi bentangan wilayah Maleo Tupa sebagian dataran rendah $137 \mathrm{ha} / \mathrm{m}^{2}$, daerah berbukit-bukit $63 \mathrm{ha} / \mathrm{m}^{2}$, dataran tinggi /pegunungan $400 \mathrm{ha} / \mathrm{m}^{2}$ dan lereng gunung $160 \mathrm{ha} / \mathrm{m}^{2}$, sehingga kondisi ini sangat berpotensi untuk dikembangkannya usaha ternak lebah madu. 
Tabel 1. Potensi, Permasalahan dan Alternatif Solusi bagi kelompok sasaran

\begin{tabular}{|c|c|c|}
\hline Potensi & Permasalahan & Alternatif Solusi \\
\hline $\begin{array}{l}\text { Wilayah Desa Maleo yang } \\
\text { sebagian besar dikelilingi } \\
\text { hutan, perbukitan dan } \\
\text { perkebunan masyarakat } \\
\text { serta berada di dataran } \\
\text { tinggi. }\end{array}$ & $\begin{array}{l}\text { Kurangnya kesadaran dan } \\
\text { perhatian masyarakat Desa } \\
\text { Maleo akan pentingnya } \\
\text { ekosistem dan } \\
\text { pemanfaatan hasil hutan }\end{array}$ & $\begin{array}{l}\text { Setelah menerima pelatihan \& } \\
\text { bimtek, masyarakat tani } \\
\text { memiliki pengetahuan \& } \\
\text { keterampilan menghasilkan } \\
\text { memanfaatkan hasil hutan } \\
\text { tanpa merusak ekosistem hutan }\end{array}$ \\
\hline $\begin{array}{l}\text { Wilayah Desa Maleo } \\
\text { mendukung untuk budidaya } \\
\text { Lebah Madu segala jenis } \\
\text { (Afis Cerana, Afis Dorsata } \\
\text { dan Triguna) }\end{array}$ & $\begin{array}{lr}\text { Keterbatasan pengetahuan } \\
\text { dan ketrampilan dalam } \\
\text { mengelola } & \text { dan }\end{array}$ & $\begin{array}{l}\text { Setelah menerima pelatihan } \\
\text { dan Bimbingan Teknik, } \\
\text { masyarakat tani mempunyai }\end{array}$ \\
\hline $\begin{array}{lrr}\text { Adanya } & \text { prakarsa } \\
\text { masyarakat } & \text { Desa } & \text { Maleo } \\
\text { untuk r memanfaatkan } & \text { potensi hutan } & \text { untuk } \\
\text { membudidayakan } & \text { Lebah } \\
\text { Madu } & \\
\end{array}$ & $\begin{array}{l}\text { membudidayakan lebah } \\
\text { madu sehingga } \\
\text { menghasilkan produk lebah } \\
\text { madu yang berkualitas }\end{array}$ & $\begin{array}{l}\text { pengetahuan bagaimana } \\
\text { mengelola dan menghasilkan } \\
\text { madu dan produk lainnya yang } \\
\text { berkualitas. }\end{array}$ \\
\hline $\begin{array}{l}\text { Madu merupakan sumber } \\
\text { komoditi yang banyak } \\
\text { diperlukan bagi industri } \\
\text { farmasi, kosmetik, dan } \\
\text { makanan, disamping } \\
\text { konsumsi sehari-hari }\end{array}$ & \multirow{2}{*}{$\begin{array}{l}\text { Upaya pengolahan hasil } \\
\text { lebah madu menemui } \\
\text { kendala teknis, baik dari } \\
\text { segi mutu, kemasan dan } \\
\text { pangsa pasar }\end{array}$} & \multirow{2}{*}{ 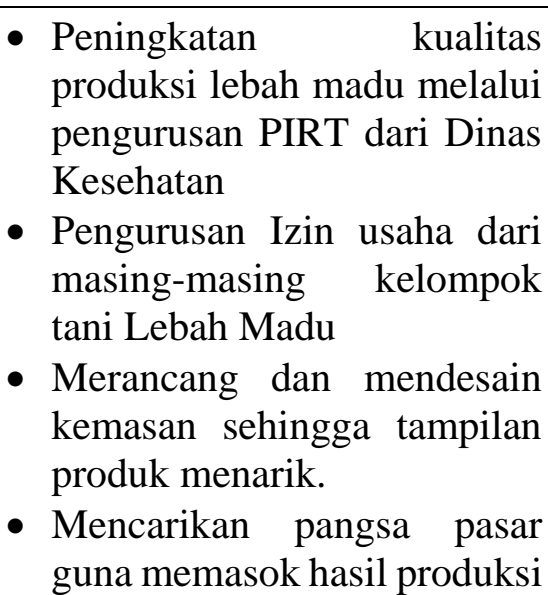 } \\
\hline $\begin{array}{l}\text { Selain produk utama adalah } \\
\text { madu, produk sekunder } \\
\text { lainnya (Royal Jelly, } \\
\text { Malam) juga sangat bernilai } \\
\text { ekonomi tinggi. }\end{array}$ & & \\
\hline
\end{tabular}

\section{Sumber: Hasil observasi \& Wawancara}

Bertolak dari permasalahan yang dikemukakan di atas kami dari staf pengajar Universitas Negeri Gorontalo mencoba memformulasikannya permasalahan tersebut ke dalam program Kuliah Kerja Sibermas (KKS) Pengabdian dengan mencoba melakukan transfer ilmu dan teknologi kepada masyarakat pengguna melalui keterlibatan mahasiswa secara langsung. Mahasiswa sejumlah 30 orang akan hidup berdampingan dengan penduduk untuk secara bersama melakukan kegiatan praktek dalam rangka penyelesaian masalah yang dihadapi selama ini. Transfer ilmu dan teknologi tersebut akan melibatkan staf dosen - mahasiswa penyuluh lapangan - dan penduduk dengan harapan memperoleh bantuan pembiayaan. 


\section{Metode}

\section{Tahap Sosialisasi dan Persiapan}

Koordinasi dengan pemerintah desa, pertemuan dengan kelompok tani lebah madu Desa Maleo serta pembicaraan awal dengan mitra telah dilakukan dimana sebagian informasi dan data yang diperoleh sudah dituangkan dalam laporan. Kemudian koordinasi dengan LPPMUNG untuk perekrutan mahasiswa yang memiliki latar belakang keilmuan bersesuaian dengan bidang kerja kelompok sasaran. Dilanjutkan pembekalan di kampus oleh akademisi dan praktisi bisnis yang kompeten dan berpengalaman selama tiga - empat hari. Pembekalan berisi materi dan teknik sosialisasi di masyarakat, penyiapan perlengkapan pendukung serta metode dan jadwal kegiatan mahasiswa selama berada dilokasi.

\section{Pelaksanaan}

Tahapan program yang akan dilaksanakan adalah pelatihan dan pendampingan Budidaya Lebah Madu. Program lain berupa bantuan teknologi peralatan, dan pemasaran. Khusus bantuan pengadaan bahan/alat untuk kegiatan pelatihan akan melibatkan mahasiswa.

Metode yang digunakan dalam melakukan pemberdayaan terhadap kelompok tani adalah teknik pembelajaran kelompok disertai praktek. Pembelajaran disertai praktek akan dilakukan oleh mahasiswa bersama-sama kelompok tani lebah madu desa Maleo.

\section{Evaluasi}

Evaluasi program akan dilakukan tiap bulan dengan menganalisa data-data input komoditas dan output produk serta tingkat serapan pasar. Evaluasi juga akan dilakukan pada kontribusi bantuan peralatan pengolahan dalam mendukung kelancaran proses. Evaluasi secara khusus juga akan dilakukan terhadap mahasiswa baik individu maupun kelompok dalam melakukan aktivitas dalam kurun waktu pelaksanaan KKS - Pengabdian di lapangan.

\section{Rencana Keberlanjutan Program}

Selain pola kinerja mahasiswa dalam KKS - Pengabdian ini, keberlanjutan program juga turut ditentukan oleh daya serap kelompok sasaran selama kegiatan pelatihan. Kemampuan kelompok sasaran dalam mengadopsi dan mengadaptasi materi yang disampaikan penyuluh teknis dan mahasiswa pendamping akan berkorelasi pada hasil; terrealisasinya budidaya lebah madu pada masing-masing kelompok tani. Ringkasnya, saling keterpaduan dan sinergi yang terbangun antara kelompok sasaran dan mahasiswa akan menentukan kesinambungan.

Penempatan mahasiswa pada semua program kegiatan adalah dalam rangka memetakan potensi dan masalah yang mungkin muncul serta solusi dan alternatifnya. Pelatihan dan bimbingan teknis mulai dari pemilihan pembuatan kandang lebah, penangkaran (penangkapan ratu dan koloni lebah) sampai pada tahap pemilihan lokasi pembudidayaan lebah madu hingga pada akhirnya proses panen madu lebah.

\section{Hasil}

Kecamatan Paguat merupakan salah satu kecamatan yang letaknya tidak jauh dari Pusat Kabupaten Pohuwato. Kecamatan ini memiliki 8 Desa/ Kelurahan (Kelurahan Libuo, Kelurahan Pentadu, Kelurahan Siduan, Desa Bumbulan, Desa Bunuyo, Desa Maleo, Desa Sipayo, Desa Soginti). Dengan luas yang ada, kecamatan ini memiliki potensi daerah terbesar di bidang perikanan tambak/air tawar, jagung dan peternakan. Masyarakat yang ada di 
Kecamatan ini sebagaian besar mata pencahariannya adalah petani ladang dan nelayan. Khususnya desa Maleo sebagaian besar warga desa ini mata pencahariannya adalah nelayan dan juga petani ladang dan sawah.

Desa Maleo sendiri terdiri dari tiga Dusun yakni Dusun satu, Dusun dua dan Dusun Tiga dengan jumlah KK 352. Desa Maleo sendiri daerahnya merupakan dataran rendah, sehingganya mata pencaharian sebagai petani dapat dikelompokkan sebagai petani sawah dan ladang. Masyarakat Desa Maleo sendiri memiliki beberapa kelompok usaha produktif, diantaranya adalah kelompok usaha tani lebah madu juga kelompok tani budidaya ikan tambak. Khusus budidaya lebah madu usaha yang dilakukan oleh kelompok usaha ini biasanya hanya merupakan usaha sampingan, sementara disatu sisi bahwa petani ini belum menyadari bahwa usaha ini sangat baik dan produktif untuk dikembangkan. Bahkan kelompok tani yang membudidayakan lebah madu ini sempat bubar dan tidak lagi meneruskan usaha tersebut.

Tim pengusul KKS Pengabdian melaksanakan observasi dan orientasi lapangan untuk mengidentifikasi permasalahan yang dialami oleh mitra dalam hal ini Pemerintah Desa dan masyarakat Desa (kelompok usaha) Desa Maleo pada umumnya. Dari kegiatan obeservasi awal oleh tim diperoleh persoalan urgen adalah ketidak mampuan masyarakat dalam menambah penghasilan ekonomi rumah tangga mereka ketika pada masa menunggu panen dan buruknya cuaca dalam berlaut, oleh karena sebagian besar penduduknya adalah bermata pencaharian Petani dan Nelayan.

\section{Usulan Program}

Dari identifikasi permasalahan tersebut, maka dapat dirumuskan usulan program yakni memberikan pemahaman dan pelatihan kepada masyarakat dalam bentuk program Pelatihan Budidaya lebah madu dalam rangka peningkatan sumber perekonomian bagi masyarakat tani desa Maleo.

\section{Pelatihan Dan Pendampingan Kelompok Usaha}

Menanggapi kebutuhan dan aspirasi mitra yakni kelompok usaha, tim pelaksana menyelenggarakan pelatihan singkat tentang teknik membudidayakan lebah madu jenis Apis Cerana disertai bimbingan teknis bagaimana membuat stup/ kandang lebah, memilih kemasan yang baik, merancang/ mendesain label kemasan serta mengambil peluang dan potensi pasar. Pelatihan ini merupakan program inti dari pelaksanaan KKS Pengabdian yang merupakan kolaborasi antara Dosen (tim Pelaksana) dan Mahasiswa sebagai peserta KKS Pengabdian periode Agustus - September. Pelatihan terdiri atas 3 sesi dengan narasumber berasal dari tenaga ahli dibidang pelatihan tersebut.

Sesi pertama berjudul Melirik Peluang dan Prospek Pasar. Tujuan dari pelatihan ini adalah diharapkan para peserta mampu untuk;

- memahami dan menerapkan prinsip pokok dalam menciptakan produk yang berdaya jual dan berdaya saing

- memahami dan menerapkan strategi pemasaran untuk pengembangan usaha

Sesi kedua "Budidaya Lebah Madu”. Tujuan dari pelatihan ini adalah diharapkan para peserta mampu untuk;

- Memahami dan menerapkan teknik membudidayakan lebah madu dengan baik

- Memahami jenis-jenis lebah madu yang baik dan mempunyai nilai ekonomi cukup baik dalam membudidayakannya

Sesi kedua dengan judul materi "Pemanfaatan Lingkungan Sebagai Sumber Pakan Lebah”. Pelatihan ini ditujukan agar peserta dapat; 
- Mampu memanfaatkan lingkungan pekarangan rumah yang mendukung ketersediaan pakan lebah madu.

- Memanfaatkan lahan-lahan tidur untuk ditanami tanaman yang bermanfaan dan berguna sebagai pakan lebah.

Para peserta adalah Kelompok tani masyarakat desa Maleo yang tersebar di 3 dusun yang ada di Desa Maleo.

\section{Bimbingan Teknis Program Inti}

Pada tahap ini dilakukan bimbingan teknik dengan mempraktekkan langsung bagaimana pembuatan stup/ kandang lebah madu, penangkapan dan penangkapan ratu lebah, dan menentukan lokasi penggembalaan lebah Proses praktek dan bimbingan ini melibatkan langsung Tim pelaksana dilapangan yakni KKS Pengabdian dan penyuluh teknis (Pakar perlebahan Prov. Gorontalo/ Ketua Kelompok Tani Lestari serta peserta KKS Pengabdian (mahasiswa).

a. Bimbingan/teknik pembuatan stup lebah.

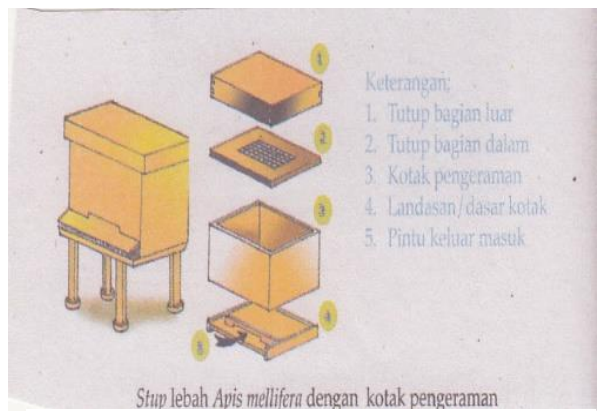

Gambar 1. Stup/ Kandang Lebah

Pada tahap ini peserta pelatihan diajarkan bagaimana membuat Stup/ kandang lebah yang baik oleh penyuluh teknis (Bpk. Nurdin Djaba) berserta tim KKS Pengabdian

Kandang lebah sendiri sebaiknya dari bahan kayu yang bersifat tidak mudah panas, tidak mudah dingin dan tahan air hujan. Ada beberapa jenis kayu yang memiliki sifat tersebut diantaranya kayu sengon, kayu cempaka dan kayu jati. Kandang dibuat dengan satu ruangan yang berfungsi untuk menampung kegiatan lebah ratu bertelur sampai menghasilkan lebah-lebah pekerja yang baru. Ruangan untuk pembiakan lebah ratu ini dinamakan ruang pengeraman. Disamping itu, lebah pekerja menghasilkan madu untuk persediaan makan larva, lebah ratu dan lebah pejantan

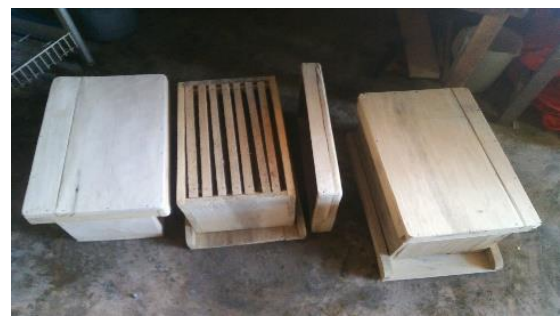

Gambar 2. Stup/ Kandang Lebah

b. Penangkapan dan penangkaran ratu lebah

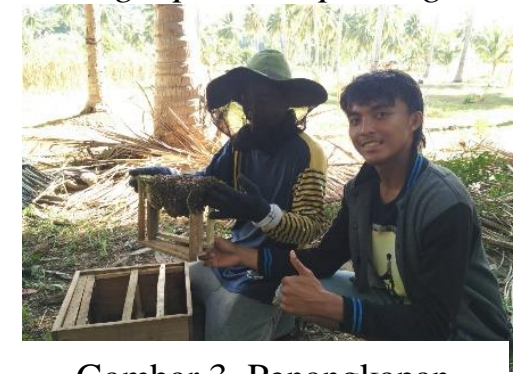

Gambar 3. Penangkapan

Ratu Lebah

Penangkapan dan penangkaran ratu lebah dilakukan langsung oleh peserta pelatihan dalam hal ini kelompok tani yang menjadi mitra binaan dalam rangka pengembangan usahanya. 
c. Menentukan lokasi penggembalaan lebah

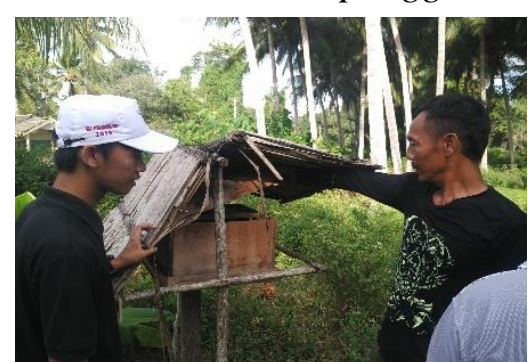

Gmb. 4 Penempatan Stup

Pada Lokasi Penggembalaan

Keberadaan dan kelangsungan hidup lebah madu tergantung pada ketersediaan makanan lebah yang berasal dari bunga tanaman. Desa Maleo sendiri merupakan daerah dengan sebagian besar dikelilingi hutan hutan lindung dengan dukungan kondisi geografis tersebut mendukung proses pengembangbiakan lebah madu.

d. Pelabelan \& pemberian merek, Pengumpulan hasil lebah madu, pengemasan, dan Pemasaran.

1. Proses penentuan dan pemberian nama atau merek serta rancangan/desain label produk madu kelompok tani desa maleo pada pelaksanaan program ini belum sepenuhnya diselesaikan, dikarenakan proses ini baru berjalan dan menurut hemat kelompok tani dalam waktu dekat ini mereka masih dalam proses pengenalan produk secara lokal ditingkat desa Maleo. Akan tetapi kami sebagai tim telah membantu dengan menyediakan beberapa bentuk kemasan dengan ukuran $360 \mathrm{ml}$ dan $250 \mathrm{ml}$ sebagai antisipasi jikalau dua bulan kemudian lebah madu ini telah berproduksi.

2. Proses Panen atau pengumpulan/ panen lebah madu dilakukan oleh kelompok tani lebah madu dibantu oleh peserta KKS Pengabdian yang dilaksanakan pada akhir pelaksanaan KKS Pengabdian.

\section{Pendampingan Program Inti}

Setelah menyelesaikan kegiatan pelatihan, tim pelaksana melakukan pendampingan ke lokasi mitra untuk menyaksikan langsung proses produksi. Disamping proses pendampingan dilakukan oleh Tim pelaksana (Dosen) juga dilakukan pendampingan langsung oleh mahasiswa peserta KKS Pengabdian yang memang sebelumnya sudah dibekali akan proses budidaya lebah madu. Proses pendampingan ini dilakukan oleh dosen dan mahasiswa selama 7 hari.

\section{Capaian Program}

Mengacu kepada target dan luaran program pada Bab 2 maka dapat disimpulkan bahwa:

a. keseluruhan tahapan kegiatan pengabdian (Pelatihan dan Pendampingan) sudah terlaksana, dampak perubahan dan kemajuan bersifat terukur.

b. Terrealisasinya luaran kegiatan berupa produk madu yang dapat dipasarkan dalam rangka meningkatkan perekonomian rumah tangga petani lebah madu jenis "apis cerana".

c. Aspek lainnya pada luaran terkait dengan program tambahan yang merupakan turunan dari program pertama juga telah terrealisasi dengan baik dalam bentuk program yang benarbenar dirasakan dan mempunyai dampak langsung bagi masyrakat Desa Maleo. 


\section{Kesimpulan}

Mengacu kepada target dan luaran program maka dapat disimpulkan bahwa:

1. Program KKS Pengabdian secara efektif membantu terlaksananya kegiatan pelatihan budidaya lebah madu pada kelompok usaha mitra yaitu Kelompok tani desa Maleo.

2. Sejumlah kendala yang dihadapi mitra pada tahap awal pelaksanaan program secara bertahap sampai proses pelaksanaan mampu dicarikan solusi dan mitra mampu melaksanakan kegiatan tersebut secara baik dan mandiri.

\section{Pengakuan/Acknowledgements}

Rasa syukur dan terima kasih kami sampaikan Kepada Yang Terhormat Kepada Desa Maleo Kecamatan Paguat Kabupaten Pohuwato yang telah bersedia menerima Mahasiswa UNG dan menjadi Lokasi Pengabdian Masyarakat. Kepada Ketua LPPM-UNG yang telah meluluskan dan memfasilitasi kegiatan KKS. Kami juga berterima kasih kepada yang kami banggakan Rektor Universitas Negeri Gorontalo dan Dekan Fakultas Ekonomi atas berkenan menyetujui kegiatan ini sejak penyusunan proposal hingga selesainya laporan hasil. Semoga Allah SWT, Tuhan Yang Maha Esa melipat gandakan pahala atas amal baik Bapak dan Ibu sekalian, Amin.

\section{Daftar Referensi}

Badan Pengelolaan Daerah Aliran Sungai (BP - DAS) Bone Bolango Provinsi Gorontalo. 2012. Data Tetap (DATAP). Gorontalo.

Kementerian Koordinator Bidang Pembangunan Manusia dan Kebudayaan. 2016. Panduan Dan Petunjuk Teknis Kuliah Kerja Nyata Revolusi Mental (KKN RM).

Pemerintah Desa Maleo. Profil Data Potensi Desa Dan Kelurahan.

Pusat Perlebahan Apiari Pramuka. Lebah Madu Cara Beternak dan Pemanfaatan. Jakarta : Penebar Swadaya, 2007.

Rusfidra, A. 2008. Tanaman Pakan Lebah Madu. http://www.bung. Di Unduh 5 Maret 2021

Samadi, Budi. 2006. Budi Daya Lebah Madu. CV. Aneka Ilmu. Demak.

Niode, Idris Yanto dan Herwin Mopangga. Manajemen Usaha : Produk Unggulan Lokal Stik Jagung Ikan. Gorontalo. Ideas Publishing. 2021. 